\title{
CHILDREN AND LIQUOR BARS: A REVIEW AND A PROPOSAL.
}

\author{
BY JOHN NEWTON, \\ Author of "W. S. Caine, M.P., a Biography," etc.
}

THE common impression upon the minds of the public is that the Children Act, 1908, prohibited children from being taken into public-houses. This impression is by no means correct. Clause 120 of the Act of 1908 forbids any licence holder to allow a child under fourteen years of age to be in the bar of any licensed premises. And a bar is said to mean "any open drinking-bar or any part of the premises exclusively or mainly used for the sale and consumption of intoxicating liquor." The prohibition, therefore, does not apply to licensed premises as a whole, but to the "bar" only, as thus defined. This law has now been in operation for four years, and it may be useful to examine some of the results.

In the first place it must be gladly recognized that the law has been in the main an enormous boon and success. Speaking generally, it has been well enforced, it has had public opinion behind it, and it has saved thousands of children from the contamination of the liquor bars. Thus it would, indeed, be difficult to overestimate the good it has done. But, like all human things, it has proved to have defects, to be less perfect than was desired or hoped, and to be open to some criticism from those captiousminded persons who are always more ready to point out failures than to work for a success.

Students of political history know that every great change in law, however necessary and beneficient, is likely to produce some results which were not anticipated, and not desired. It always has been so, and probably always will be so. One effect produced in this case is much to be regretted, and that is, the custom of mothers and fathers to leave their children on the 
pavement outside for long periods, whilst they remain drinking inside the public-houses. In many of our large centres of population, even in inclement weather, groups of little children may be seen so left, and often to a late hour at night. This is a scandal which calls aloud for redress, not, as some have suggested, by allowing the children to enter the liquor bars again, but by stiffening either the administration or the law with regard to undue exposure, or both, and, if necessary, by attempting to define the time allowed for " reasonable refreshment." This last suggestion no doubt would be rather difficult of adoption, but no one can reasonably claim that two hours, for instance, is necessary for any person to obtain "reasonable refreshment." Relaxation of the law would be a sadly reactionary step.

Both the health and the morals of the children may be corrupted by admission to the liquor bars, as was recognized when the Act was passed, whilst health only is risked by their being left outside. This is not said to excuse the practice, nor to minimize the evil results of it, but to show that the present state of things, however undesirable, is less injurious than the former.

Another much-criticized undesirable result which obtains in many districts is presented by the spectacle of mothers with babies in their arms standing round the doors of public-houses drinking. One clergyman, writing on the subject, calls it "a scandal," though whether he means that the act of drinking by nursing mothers, or the fact that they drink in public, is a scandal, is not clear. We can all agree that it is a most undesirable and dangerous practice. But the fact that nursing mothers drink cannot be credited to the operation of the Ghildren Act. And if one result of drinking on the streets is to produce disgust in the minds of the public, all the better. It is the first step to reform, in which, of course, moral education must accompany legislation.

Another undesirable practice which has grown up since the law came into operation is as follows. In a number of large towns in England publicans have adopted the custom of placing notices in their windows to the effect that there are special rooms provided for women and children. In Rochester, for instance, notices appeared-."Private room for ladies and children."

Inquiries addressed by the Children's Protection League to the Chief Constables of England and Scotland elicited over 100 replies which showed that, whilst in the vast majority of cases the law was carried out in its spirit as well as its letter, there were 
in many cases widely diverging interpretations of police duty under its provisions. In a certain county there are two neighbouring boroughs. In one of them such notices as are referred to above are allowed, and are thought by the Chief Constable to be entirely proper, whilst the other Chief Constable says such notices do not appear, and would not be allowed if attempted.

A fair number of officers say if such notices appeared they would either report the matter to the justices, or oppose the renewals of the licences. Others, again, say the publicans are only attending to their own interests in posting up such notices. It will be generally admitted that such diversity of administration is not good, and that all officers ought to be brought up to the level of the best. Probably a communication from the Home Office might have the desired effect.

Let us quote again the definition of a bar: "Any part of the premises exclusively or mainly used for the sale and consumption of intoxicating liquor." The words in italics are the important words here. A moment's thought will show how great the change would be if the words read "sale or consumption." As the law stands now, the liquor must be ordered, drawn, served, paid for, and consumed, at one and the same time and place. In practice it is beginning to be found that there are serious loopholes, and that the clause needs strengthening. For instance, in Bridgwater, Somerset, the police found in a publichouse smoke-room sixteen persons, male and female, with three children of eight years of age. The adults were drinking and smoking. The police prosecuted. The defence was that "sale and consumption" did not take place in the room, but consumption only. Apparently, although an order could be given in the smoke-room, and the liquor consumed there, the act of sale took place in the bar, where the liquor was pumped into the glasses. At least the magistrates appear to have so decided, for they dismissed the summons. If this is sound in law it is bad in morals. In Glasgow there was another case which also seems to show that the law needs strengthening. This particular public-house had a long bar from which was cut off, by a wooden partition 7 feet high, a space 6 feet square. This was called a luncheon bar. Whether the entrance was through the bar is not clear from the published reports, but presumably it was. In this small space of 6 feet square the police found three women drinking rum, each with a child in her arms. They prosecuted the publican, and the magistrate held, and one would say quite rightly, that any child in this 
box was exposed to the sights, sounds, and influences of the bar, to all intents and purposes. He therefore convicted. The publican appealed to Edinburgh, and the conviction was quashed.

These two cases show that the law, as drawn, fails to achieve its complete purpose, and needs strengthening. If the words "sale or consumption" were, without qualification, substituted for the words "sale and consumption" they might carry us farther than public opinion at present warrants, as under them it might be illegal for a child to be sent to a licensed grocer's shop. But it would be comparatively easy to use the suggested words, subject to exemptions applying to hotels for eating and lodging, to restaurants for meals, and to licensed grocers. There would thus be no hardship inflicted upon those who were legitimately using these places for purposes other than mere drinking.

This brief review shows that such defects as have revealed themselves in the working of this salutary law could comparatively easily be remedied, and the experiences gained thus far, would, I think, justify the Government in introducing some such reforms as are here suggested in their next Licensing Bill. Further, $I$ believe public opinion would support them in raising the age from fourteen to sixteen, under which no child should go in a liquor bar, and the age from five to ten under which no intoxicants could be given to a child as a beverage. Even at sixteen our law would be behind many of the States of the American Union, about half of which fix the age at twenty-one. 